\title{
Governing the dead
}

Sovereignty and the politics of dead bodies

Edited by FINN STEPPUTAT

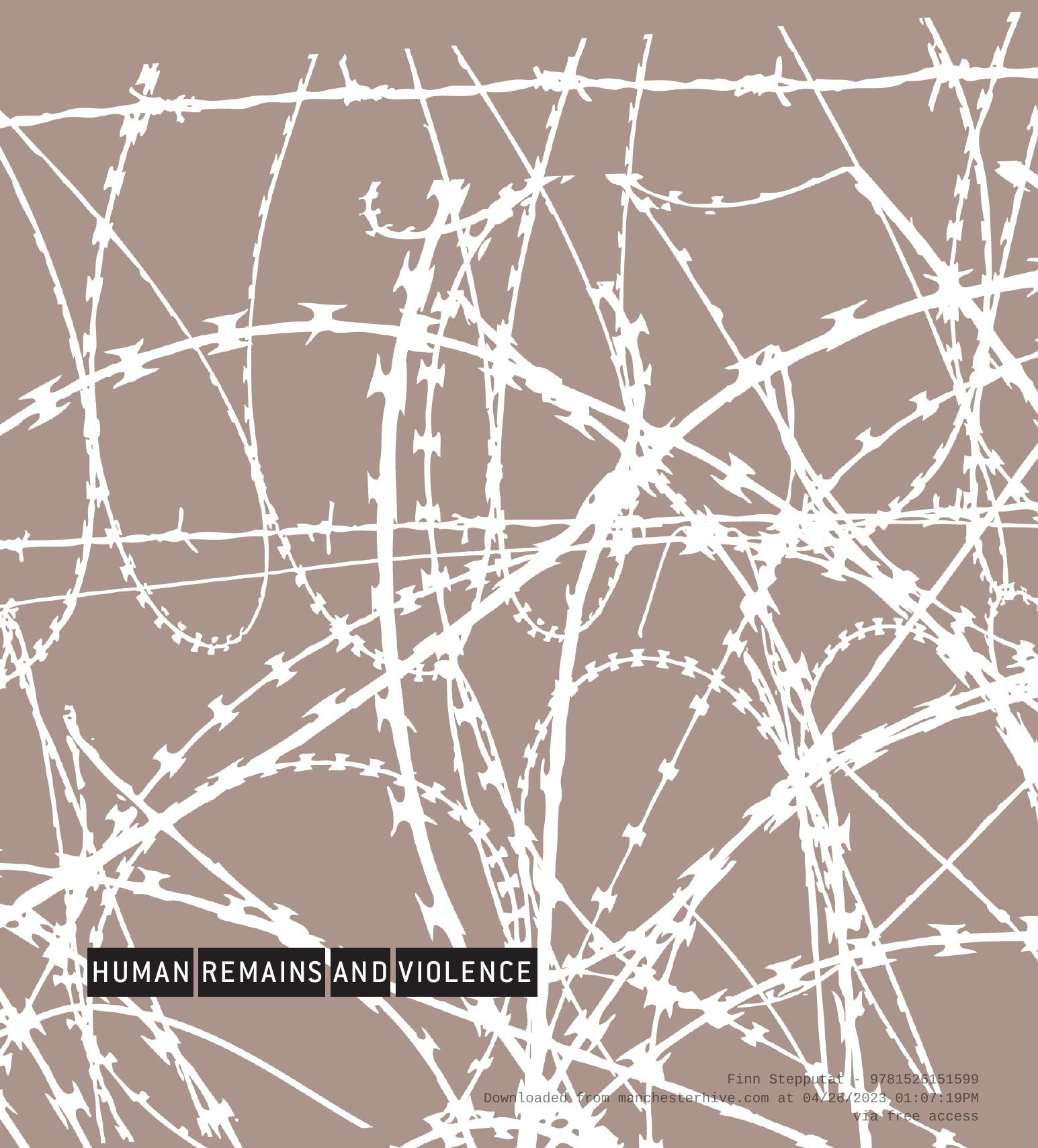


Finn Stepputat - 9781526151599

Downloaded from manchesterhive.com at 04/26/2023 01:07:19PM

via free access 


\section{Governing the dead}

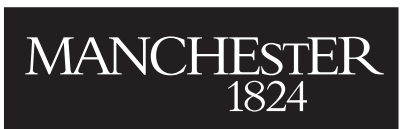

Manchester University Press 


\section{HUMAN REMAINS AND VIOLENCE}

Human remains and violence aims to question the social legacy of mass violence by studying how different societies have coped with the dead bodies resulting from war, genocide and state-sponsored brutality. However, rather paradoxically, given the large volume of work devoted to the body on the one hand, and to mass violence on the other, the question of the body in the context of mass violence remains a largely unexplored area and even an academic blind spot. Interdisciplinary in nature, Human remains and violence intends to show how various social and cultural treatments of the dead body simultaneously challenge common representations, legal practices and morality. This series aims to provide proper intellectual and theoretical tools for a better understanding of mass violence's aftermaths in today's societies.

\section{Series editors}

Jean-Marc Dreyfus and Élisabeth Anstett

\section{ALSO AVAILABLE IN THIS SERIES}

Destruction and human remains: disposal and concealment in genocide and mass violence

Edited by Élisabeth Anstett and Jean-Marc Dreyfus 


\section{Governing the dead}

Sovereignty and the politics of dead bodies

\section{Edited by}

Finn Stepputat

\section{Manchester University Press}

Manchester and New York

distributed in the United States exclusively by Palgrave Macmillan 
The right of Finn Stepputat to be identified as the author of this work has been asserted by him in accordance with the Copyright, Designs and Patents Act 1988.

Published by Manchester University Press

Oxford Road, Manchester M13 9NR, UK

and Room 400, 175 Fifth Avenue, New York, NY 10010, USA

www.manchesteruniversitypress.co.uk

Distributed in the United States exclusively by

Palgrave Macmillan, 175 Fifth Avenue, New York,

NY 10010, USA

Distributed in Canada exclusively by

UBC Press, University of British Columbia, 2029 West Mall,

Vancouver, BC, Canada V6T 1 Z2

British Library Cataloguing-in-Publication Data

A catalogue record for this book is available from the British Library

Library of Congress Cataloging-in-Publication Data applied for

ISBN 9780719096082 hardback

First published 2014

The publisher has no responsibility for the persistence or accuracy of URLs for any external or third-party internet websites referred to in this book, and does not guarantee that any content on such websites is, or will remain, accurate or appropriate.

Typeset

by Out of House Publishing 